\title{
Contribution of Cytogenetics to the Debate on the Paraphyly of Pachycondyla spp. (Hymenoptera, Formicidae, Ponerinae)
}

\author{
Cléa dos Santos Ferreira Mariano, ${ }^{1,2}$ Silvia das Graças Pompolo, ${ }^{3}$ \\ Janisete Gomes Silva, ${ }^{1}$ and Jacques Hubert Charles Delabie ${ }^{2,4}$ \\ ${ }^{1}$ Departamento de Ciências Biológicas, Universidade Estadual de Santa Cruz, Km 16 Rodovia Ilhéus-Itabuna, \\ 45650-000 Ilhéus, BA, Brazil \\ ${ }^{2}$ Laboratório de Mirmecologia, Centro de Pesquisas do Cacau (CEPEC/CEPLAC), Caixa Postal 7, \\ 45600-000 Itabuna, BA, Brazil \\ ${ }^{3}$ Laboratório de Citogenética de Insetos, Departamento de Biologia Geral, Universidade Federal de Viçosa, \\ 35570-000 Viçosa, MG, Brazil \\ ${ }^{4}$ Departamento de Ciências Agrárias e Ambientais, Universidade Estadual de Santa Cruz, \\ Km 16 rodovia Ilhéus-Itabuna, 45650-000 Ilhéus, BA, Brazil
}

Correspondence should be addressed to Cléa dos Santos Ferreira Mariano, camponotu@hotmail.com

Received 16 June 2011; Accepted 29 July 2011

Academic Editor: Fernando Fernández

Copyright (C) 2012 Cléa dos Santos Ferreira Mariano et al. This is an open access article distributed under the Creative Commons Attribution License, which permits unrestricted use, distribution, and reproduction in any medium, provided the original work is properly cited.

\begin{abstract}
We present evidence of the paraphyly of the ant genus Pachycondyla resulting from our cytogenetic studies on 29 populations in 18 species from Brazil and French Guyana. It is likely that karyotypes with a large number of chromosomes and comprising mostly small acrocentric chromosomes in species within the Pachycondyla stricto sensu group resulted from a succession of centric fission events. On the other hand, karyotypes with a small chromosome number comprising mostly metacentric chromosomes are also interpreted as little derived and tend to undergo centric fission. The karyotypes of the group Neoponera are more heterogeneous and probably undergo successive cycles of rearrangements tending to increase the chromosome number by centric fission. The apicalis and verenae complexes form two probable sister groups that evolved independently due to centric fissions (verenae) and pericentric inversions (apicalis). Our results reveal the karyotype diversity in the genus and reinforce the hypothesis on the paraphyly of Pachycondyla.
\end{abstract}

\section{Introduction}

Among the Ponerinae, the genus Pachycondyla (Ponerinae, Ponerini) is one of the most ancient known genera of ants and still extant. A fossil species, Pachycondyla rebekkae Rust and Andersen, was found in calcareous rocks from the early Tertiary $( \pm 55$ million years $)$ in formations in northwest Denmark [1]. The current distribution of this genus (Pachycondyla sensu Brown, in Bolton, [2]) is pantropical with 197 valid species [3, 4]. A recent review of the New World species of Pachycondyla reports 92 species alone in the Neotropics and characterizes 18 complexes of species based on morphological characters [4].

According to Kempf [5], Pachycondyla comprised only 10 species in the Neotropical region, whereas other Neotropical taxa currently included in this group $[3,4]$ were distributed within the genera Neoponera, Mesoponera, Pachycondyla, Termitopone, and Trachymesopus in his catalogue. This classification was maintained until Bolton [2] proposed a synonymization based on arguments already discussed by Brown [6]. According to Schmidt's conclusions [7], and recently commented by Ward [8] who called it the "Pachycondyla problem," the group of ants currently denominated "genus Pachycondyla" is paraphyletic. Taking into account only the Neotropical taxa, this taxon would comprise six species groups (according to Schmidt's classification) not necessarily related.

Cytogenetic studies on insects not only can significantly contribute to the understanding of morphological characteristics but also can shed some light on taxonomic and 
evolutionary aspects, as, for instance, on groups of species in sympatry [9] competing for the same resources or cryptic species complexes $[10,11]$. In the order Hymenoptera, cytotaxonomy has been used by Baldanza et al. [12], Hoshiba and Imai [13], Gokhman [14], and Gokhman and Kuznetsova [15] as a character for taxonomic and evolutionary studies. The determination of a karyotype and the occasional observation of the occurrence of chromosome rearrangements are especially important to make inferences regarding evolutionary or speciation processes. Since gene expression is regulated at least partially by the location of neighboring genes, chromosome alterations can result in phenotype alterations [16] and drive speciation processes. Thus, the understanding of karyotype evolution is valuable for evolutionary, phylogenetic, and taxonomic studies [17, 18 ] and can be used as a tool to evaluate species diversity.

Regarding Formicidae, Lorite and Palomeque [19] report more than 750 morphospecies with known chromosome number, which is still a relatively small number considering the diversity of this family estimated to be about 21.000 species [20]. In the Ponerinae, cytogenetic studies have been published for 95 morphospecies in 12 genera with chromosome numbers ranging between $2 n=8$ and $2 n=$ 120 [19], which is a considerable variation when compared to the remaining ant families, except for Myrmeciinae. It is noteworthy that karyotype variation among populations of the same species is frequent in the genera Myrmecia [21] and Pachycondyla [22-25]. Among the Ponerinae, Pachycondyla has been the most studied genus (40 morphospecies) and also the one with the highest variation in chromosome number $2 n=12-104$ [19]. Several hypotheses have been tested to understand karyotype evolution in ants including the fusion, fission, and modal hypotheses summarized by Imai et al. ([26], see also [19, 27]). In 1988, Imai and collaborators proposed the Minimum Interaction Theory that states that the chromosome interactions in the interphasic nucleus are responsible for changes in the karyotypes $[28,29]$. The same research group [21, 27] developed the karyographic method as a tool that allows to visually explain karyotype evolutionary processes based on metaphase rearrangements. Although this method has not been much used [18, 21, 30$32]$, it is the only way to compare a large set of karyotype data and make inferences about the studied groups, except for comparative studies using molecular cytogenetic techniques $[33,34]$.

According to Lorite and Palomeque [19], the chromosome groups reported in Formicidae suggest the occurrence of different patterns of karyotype evolution in different taxonomic groups. Aiming at contributing to the knowledge of Neotropical poneromorphs, our research group has been developing interdisciplinary studies on different species of the subfamily Ponerinae. In this study, we investigated a series of Neotropical taxa within the genus Pachycondyla sensu Brown (Table 1) whose monophyly has been questioned by some authors [7, 23]. We also discussed hypotheses regarding the evolution of lineages that comprise this taxon, which is so important for the conservation of forest biomes in the Neotropical region [4].

\section{Material and Methods}

Colonies of Pachycondyla spp. were collected in 13 localities (Table 2) in several states in Brazil and in French Guyana in areas of the Atlantic rainforest, cocoa plantations, Caatinga, and the Amazonian rainforest between 2000 and 2010. In order to make comparisons feasible, we used original and published information as shown in Table 2.

Species identification was carried out following the review by MacKay and MacKay [4] and the species complexes proposed by them. However, aiming at comparing the studied taxa, we also refer to the previous classification by Kempf [5], to the synonymization of different genera of Ponerinae under Pachycondyla by Brown in Bolton [2] and to a recent generic reclassification proposed by Schmidt [7] but still not fully formalized (Table 1).

Mitotic metaphases were obtained from cerebral ganglia and male gonads treated with $0.005 \%$ colchicine for $20-40$ minutes and the chromosomes were stained with Giemsa 2\% according to Imai et al. [29]. The images were captured using Image-Pro Discovery version 4.5 software under a clear field microscope. Metaphases of some the taxa studied were used to exemplify chromosome patterns.

Our analyses were based on chromosome number and morphology. Unpublished information or available in literature [19, 35-37, Mariano et al., unpublished information] on chromosome number and their structure in the Ponerinae subfamily and for Pachycondyla sensu Brown is used for comparison. Chromosomes were classified according to Imai's terminology [38]. The karyotypes studied were grouped and compared mainly based on Schmidt's classification [7]. Inferences on karyotype evolution in groups within Pachycondyla sensu Brown were carried out based on karyographs following Imai and Crozier [27] and Imai et al. [21]. Such an analysis allows for the discussion of the direction of karyotype evolution at the taxonomic group level (Figures 1 and 6).

\section{Results}

A graphic comparison of the karyotype diversity among Neotropical species of Ponerinae and the taxa within the genus Pachycondyla sensu Brown is shown in a histogram (Figure 2). Species within the genus Pachycondyla sensu Brown and the Neotropical species in the same genus were discriminated from the remaining genera belonging to the subfamily Ponerinae. We found an ample chromosome variation, which had already been observed in Ponerinae, showing the extreme karyotype heterogeneity within this subfamily, especially when compared with the remaining subfamilies of Formicidae, except for the Australian Myrmeciinae [19].

The Neotropical taxa within the genus Pachycondyla sensu Brown studied and their respective classification according to Kempf [5], Bolton [2], Schmidt [7], and MacKay and MacKay [4] are listed in Table 1. Our results comprise four groups similar to Schmidt's proposal [7], and among these groups, Neoponera was the largest in this study and also the group with the most variable chromosome 
TABLE 1: List of species considered here, generic classification according to Kempf, 1972 [5]; Brown [6] in Bolton, 1995 [2]; Schmidt's (2009) proposition for genera names; Pachycondyla species complex according to MacKay and MacKay's [4] and taxonomic unit names used in this study and based on ecological, cytogenetic, and morphological evidences.

\begin{tabular}{|c|c|c|c|c|c|}
\hline Pachycondyla species & $\begin{array}{c}\text { Genera } \\
\text { according to } \\
\text { Kempf, } 1972 \\
{[5]}\end{array}$ & $\begin{array}{c}\text { Genus } \\
\text { according to } \\
\text { Brown in } \\
\text { Bolton, } 1995 \\
{[2]}\end{array}$ & $\begin{array}{l}\text { Schmidt's (2009) genera } \\
\text { name proposition }\end{array}$ & $\begin{array}{c}\text { MacKay and } \\
\text { MacKay's [4] } \\
\text { Pachycondyla } \\
\text { species complex }\end{array}$ & $\begin{array}{l}\text { Name of the } \\
\text { taxonomic unit } \\
\text { used in this study }\end{array}$ \\
\hline $\begin{array}{l}\text { Pachycondyla apicalis } \\
\text { (Latreille, 1802) }\end{array}$ & Neoponera & Pachycondyla & Neoponera & apicalis & Neoponera-apicalis \\
\hline $\begin{array}{l}\text { Pachycondyla arhuaca } \\
\text { (Forel, 1901) }\end{array}$ & Mesoponera & Pachycondyla & Pachycondyla (Incertae Sedis) & arhuaca & - \\
\hline $\begin{array}{l}\text { Pachycondyla carinulata } \\
\text { (Roger, 1861) }\end{array}$ & Neoponera & Pachycondyla & Neoponera & crenata & Neoponera-crenata \\
\hline $\begin{array}{l}\text { Pachycondyla concava } \\
\text { (Mackay and Mackay, 2010) }\end{array}$ & - & Pachycondyla & - & emiliae & Neoponera-emiliae \\
\hline $\begin{array}{l}\text { Pachycondyla constricta } \\
\text { (Mayr, 1884) }\end{array}$ & Mesoponera & Pachycondyla & Mayaponera & constricta & - \\
\hline $\begin{array}{l}\text { Pachycondyla crassinoda } \\
\text { (Latreille, 1802) }\end{array}$ & Pachycondyla & Pachycondyla & Pachycondyla & crassinoda & Pachycondyla \\
\hline $\begin{array}{l}\text { Pachycondyla crenata } \\
\text { (F Smith, 1858) }\end{array}$ & Neoponera & Pachycondyla & Neoponera & crenata & Neoponera-crenata \\
\hline $\begin{array}{l}\text { Pachycondyla curvinodis } \\
\text { (Forel, 1899) }\end{array}$ & Neoponera & Pachycondyla & Neoponera & foetida & Neoponera-foetida \\
\hline $\begin{array}{l}\text { Pachycondyla gilberti } \\
\text { (Kempf, 1960) }\end{array}$ & Trachymesopus & Pachycondyla & Pseudoponera & stigma & Pseudoponera \\
\hline $\begin{array}{l}\text { Pachycondyla goeldii (Forel, } \\
\text { 1912) }\end{array}$ & Neoponera & Pachycondyla & Neoponera & crenata & Neoponera-crenata \\
\hline $\begin{array}{l}\text { Pachycondyla harpax } \\
\text { (Fabricius, 1804) }\end{array}$ & Pachycondyla & Pachycondyla & Pachycondyla & crassinoda & Pachycondyla \\
\hline $\begin{array}{l}\text { Pachycondyla impressa } \\
\text { (Roger, 1861) }\end{array}$ & Pachycondyla & Pachycondyla & Pachycondyla & crassinoda & Pachycondyla \\
\hline $\begin{array}{l}\text { Pachycondyla inversa } \\
\text { (F Smith, 1858) }\end{array}$ & Neoponera & Pachycondyla & Neoponera & foetida & Neoponera-foetida \\
\hline $\begin{array}{l}\text { Pachycondyla marginata } \\
\text { (Roger, 1861) }\end{array}$ & Termitopone & Pachycondyla & Neoponera & laevigata & Neoponera \\
\hline $\begin{array}{l}\text { Pachycondyla metanotalis } \\
\text { (Luederwaldt, 1918) }\end{array}$ & Pachycondyla & Pachycondyla & Neoponera & emiliae & Pachycondyla \\
\hline $\begin{array}{l}\text { Pachycondyla moesta (Mayr, } \\
1870 \text { ) }\end{array}$ & Neoponera & Pachycondyla & Neoponera & crenata & Neoponera-crenata \\
\hline $\begin{array}{l}\text { Pachycondyla stigma } \\
\text { (Fabricius, 1804) }\end{array}$ & Trachymesopus & Pachycondyla & Pseudoponera & stigma & Pseudoponera \\
\hline $\begin{array}{l}\text { Pachycondyla striata (Smith, } \\
1858 \text { ) }\end{array}$ & Pachycondyla & Pachycondyla & Pachycondyla & crassinoda & Pachycondyla \\
\hline $\begin{array}{l}\text { Pachycondyla succedanea } \\
\text { (Roger, 1863) }\end{array}$ & Trachymesopus & Pachycondyla & Pseudoponera & stigma & Pseudoponera \\
\hline $\begin{array}{l}\text { Pachycondyla unidentata } \\
\text { Mayr, } 1862\end{array}$ & Neoponera & Pachycondyla & Neoponera & crenata & Neoponera-crenata \\
\hline $\begin{array}{l}\text { Pachycondyla venusta } \\
\text { (Forel, 1912) }\end{array}$ & Neoponera & Pachycondyla & - & emiliae & Neoponera-emiliae \\
\hline $\begin{array}{l}\text { Pachycondyla verenae } \\
\text { (Forel, 1922) }\end{array}$ & Neoponera & Pachycondyla & Neoponera & apicalis & Neoponera-verenae \\
\hline $\begin{array}{l}\text { Pachycondyla villosa } \\
\text { (Fabricius, 1804) }\end{array}$ & Neoponera & Pachycondyla & Neoponera & foetida & Neoponera-foetida \\
\hline
\end{tabular}


TAble 2: Chromosome number and karyotypes of 29 Neotropical Pachycondyla populations/species. FG: French Guyana, others: Brazil: BA: state of Bahia, MG: state of Minas Gerais, SP: state of São Paulo. * Referred to as P. gp. venusta in the original publication.

\begin{tabular}{|c|c|c|c|c|}
\hline Species & $2 n$ & Karyotype & Locality/coordinates & Reference \\
\hline P. apicalis & $2 n=36$ & $28 \mathrm{M}+8 \mathrm{~A}$ & Ilhéus-BA; $14^{\circ} 45^{\prime} \mathrm{S} 39^{\circ} 13^{\prime} \mathrm{W}$ & {$[25]$} \\
\hline P. apicalis & $2 n=40$ & $30 \mathrm{M}+10 \mathrm{~A}$ & Belmonte-BA; $16^{\circ} 05^{\prime} \mathrm{S} 39^{\circ} 12^{\prime} \mathrm{W}$ & {$[25]$} \\
\hline P. apicalis & $2 n=68$ & $48 \mathrm{M}+20 \mathrm{~A}$ & Uruçuça-BA; $14^{\circ} 34^{\prime} \mathrm{S} 39^{\circ} 16^{\prime} \mathrm{W}$ & {$[25]$} \\
\hline P. arhuaca & $2 n=36$ & $36 \mathrm{~A}$ & FG: Chutes Voltaire $05^{\circ} 27^{\prime} \mathrm{N} 54^{\circ} 03^{\prime} \mathrm{W}$ & this study \\
\hline P. concava* & $2 n=54$ & $6 \mathrm{M}+48 \mathrm{~A}$ & Itororó-BA; $15^{\circ} 7^{\prime} \mathrm{S} 40^{\circ} 5^{\prime} \mathrm{W}$ & {$[35]$} \\
\hline P. carinulata & $2 n=24$ & $4 \mathrm{M}+20 \mathrm{~A}$ & Ilhéus-BA; $14^{\circ} 45^{\prime} \mathrm{S} 39^{\circ} 13^{\prime} \mathrm{W}$ & {$[35]$} \\
\hline P. constricta & $2 n=30$ & $30 \mathrm{~A}$ & Ilhéus-BA; $14^{\circ} 45^{\prime} \mathrm{S} 39^{\circ} 13^{\prime} \mathrm{W}$ & {$[35]$} \\
\hline P. crassinoda & $2 n=62$ & $22 \mathrm{M}+40 \mathrm{~A}$ & Ilhéus-BA; $14^{\circ} 45^{\prime} \mathrm{S} 39^{\circ} 13^{\prime} \mathrm{W}$ & {$[14]$} \\
\hline P. crenata & $2 n=26$ & $2 \mathrm{M}+24 \mathrm{~A}$ & Viçosa-MG; $20^{\circ} 45^{\prime} \mathrm{S} 45^{\circ} 52^{\prime} \mathrm{W}$ & {$[23]$} \\
\hline P. curvinodis & $2 n=26$ & $4 \mathrm{M}+22 \mathrm{~A}$ & Ilhéus-BA; $14^{\circ} 45^{\prime} \mathrm{S} 39^{\circ} 13^{\prime} \mathrm{W}$ & {$[35]$} \\
\hline P. curvinodis & $2 n=28$ & $22 \mathrm{M}+6 \mathrm{~A}$ & Una-BA; $15^{\circ} 16^{\prime} \mathrm{S} 39^{\circ} 05^{\prime} \mathrm{W}$ & {$[35]$} \\
\hline P. gilberti & $2 n=12$ & $10 \mathrm{M}+2 \mathrm{~A}$ & Arataca-BA; $15^{\circ} 15^{\prime} \mathrm{S} 39^{\circ} 24^{\prime} \mathrm{W}$ & this study \\
\hline P. goeldii & $2 n=24$ & $24 \mathrm{~A}$ & FG: Petit Saut; $05^{\circ} 20^{\prime} \mathrm{N} 53^{\circ} 41^{\prime} \mathrm{W}$ & {$[35]$} \\
\hline P. harpax & $2 n=96$ & $12 \mathrm{M}+84 \mathrm{~A}$ & Ilhéus-BA; $14^{\circ} 45^{\prime} \mathrm{S} 39^{\circ} 13^{\prime} \mathrm{W}$ & {$[24]$} \\
\hline P. impressa & $2 n=94$ & $8 \mathrm{M}+86 \mathrm{~A}$ & Ibicuí-BA; $14^{\circ} 53^{\prime} \mathrm{S} 40^{\circ} 02^{\prime} \mathrm{W}$ & this study \\
\hline P. inversa & $2 n=30$ & $20 \mathrm{M}+10 \mathrm{~A}$ & Ilhéus-BA; $14^{\circ} 45^{\prime} \mathrm{S} 39^{\circ} 13^{\prime} \mathrm{W}$ & {$[35]$} \\
\hline P. marginata & $2 n=46$ & $28 \mathrm{M}+18 \mathrm{~A}$ & Viçosa-MG; $20^{\circ} 45^{\prime} \mathrm{S} 45^{\circ} 52^{\prime} \mathrm{W}$ & {$[35]$} \\
\hline P. moesta & $2 n=26$ & $26 \mathrm{~A}$ & Viçosa-MG; $20^{\circ} 45^{\prime} \mathrm{S} 45^{\circ} 52^{\prime} \mathrm{W}$ & {$[23]$} \\
\hline P. metanotalis & $2 n=70$ & $16 \mathrm{M}+54 \mathrm{~A}$ & Camacã-BA; $15^{\circ} 23^{\prime} \mathrm{S} 39^{\circ} 33^{\prime} \mathrm{W}$ & this study \\
\hline P. stigma & $2 n=12$ & $12 \mathrm{M}$ & Porto Seguro-BA; $16^{\circ} 23^{\prime} \mathrm{S} 39^{\circ} 10^{\prime} \mathrm{W}$ & this study \\
\hline P. striata & $2 n=104$ & $4 \mathrm{M}+100 \mathrm{~A}$ & Camacã-BA; $15^{\circ} 23^{\prime} \mathrm{S} 39^{\circ} 33^{\prime} \mathrm{W}$ & {$[24]$} \\
\hline P. succedanea & $2 n=14$ & $14 \mathrm{M}$ & FG: Chutes Voltaire $05^{\circ} 27^{\prime} \mathrm{N} 54^{\circ} 03^{\prime} \mathrm{W}$ & this study \\
\hline P. unidentata & $2 n=12$ & $12 \mathrm{M}$ & Ilhéus-BA; $14^{\circ} 45^{\prime} \mathrm{S} 39^{\circ} 13^{\prime} \mathrm{W}$ & {$[35]$} \\
\hline P. venusta & $2 n=48$ & $26 \mathrm{M}+22 \mathrm{~A}$ & Viçosa-MG; $20^{\circ} 45^{\prime} \mathrm{S} 45^{\circ} 52^{\prime} \mathrm{W}$ & {$[35]$} \\
\hline P. verenae & $2 n=42$ & $30 \mathrm{M}+12 \mathrm{~A}$ & Ilhéus-BA; $14^{\circ} 45^{\prime} \mathrm{S} 39^{\circ} 13^{\prime} \mathrm{W}$ & {$[25]$} \\
\hline P. verenae & $2 n=62$ & $14 \mathrm{M}+48 \mathrm{~A}$ & Ilhéus-BA; $14^{\circ} 45^{\prime} \mathrm{S} 39^{\circ} 13^{\prime} \mathrm{W}$ & {$[25]$} \\
\hline P. verenae & $2 n=58-60$ & $14 \mathrm{M}+44 \mathrm{~A}$ & Viçosa-MG; $20^{\circ} 45^{\prime} \mathrm{S} 45^{\circ} 52^{\prime} \mathrm{W}$ & {$[25]$} \\
\hline P. verenae & $2 n=64$ & $12 \mathrm{M}+52 \mathrm{~A}$ & Rio Claro-SP; $22^{\circ} 23^{\prime} \mathrm{S} 47^{\circ} 32^{\prime} \mathrm{W}$ & {$[25]$} \\
\hline P. villosa & $2 n=34$ & $12 \mathrm{M}+22 \mathrm{~A}$ & Ilhéus-BA; $14^{\circ} 45^{\prime} \mathrm{S} 39^{\circ} 13^{\prime} \mathrm{W}$ & {$[35]$} \\
\hline
\end{tabular}

number and karyotypes (Table 2). We present information on taxa within nine of the 18 species complexes defined by MacKay and MacKay [4] (Table 2). When comparing these classifications, there is unanimity among the authors solely on the Pachycondyla stricto sensu group. There is a certain consensus regarding the group Neoponera according to Kempf's catalogue [5] and Schmidt's proposal [7] (Table 1). Although Schmidt [7, page 197] has placed Pachycondyla metanotalis Luederwaldt, 1918 in his clade Neoponera, we followed Kempf's classification [5] for the aforementioned species since Schmidt's proposal is not backed by any new data, for the fact that $P$. metanotalis is a soil-dwelling species as most species in the clade Pachycondyla [5, 7], for morphological criteria not detailed herein, and because its karyotype is much closer to other species in the Pachycondyla stricto sensu group than to the Neoponera in this study.

A total of 29 populations was studied (Table 2), and several different populations were sampled for some taxa, therefore each line in this table represents one of these such populations as they can have different karyotypes with distinct characteristics. The chromosomes are classified [38] according to if they are acrocentric (A) or metacentric (M). The chromosome complements found are extremely variable showing from a few metacentric chromosomes $(2 n=12)$ of large size (Pachycondyla unidentata Mayr, 1862) to a large number of minute acrocentric chromosomes $(2 n=$ 104 in Pachycondyla striata (Smith, 1858) (Table 2) and confirming the tendency shown in Figure 1: karyotypes with a few chromosomes have large chromosomes whereas karyotypes with a large number of chromosomes have small chromosomes (see examples in Figure 3).

The simple observation of chromosome morphology reveals great similarity among karyotypes of Pachycondyla crassinoda (Latreille, 1802), Pachycondyla harpax (Fabricius, 1804), Pachycondyla impressa Roger, 1861, P. metanotalis, and P. striata (group Pachycondyla sensu stricto) and also in the karyotypes of Pachycondyla gilberti (Kempf, 1960), Pachycondyla succedanea (Roger, 1863), and Pachycondyla 


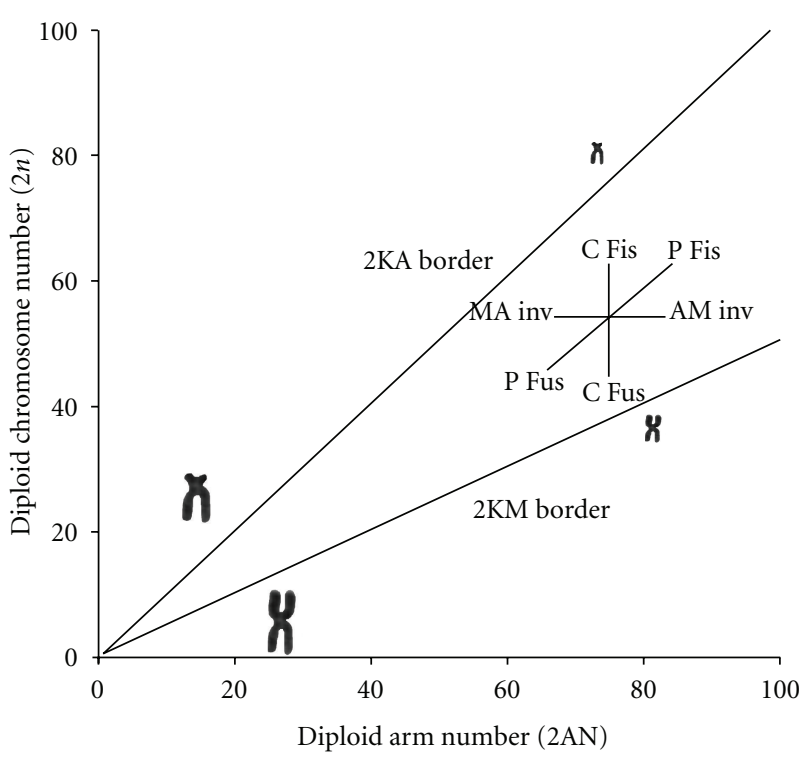

FIGURE 1: Karyograph adapted from Imai et al. [21] for ants. Since the genome is approximately constant for the whole Formicidae family, a proportional smaller chromosome size corresponds to the increase in the chromosome number. $2 \mathrm{KA}$ border: upper limit to the number of acrocentric chromosomes in diploid cells; $2 \mathrm{KM}$ border: lower limit to the number of metacentric chromosomes in diploid cells. C Fis: centric fission, C Fus: centric fusion, P Fis: pericentric fission, P Fus: pericentric fusion, AM inv: acrocentric-metacentric inversion, MA inv: metacentric-acrocentric inversion.

stigma (Fabricius, 1804) (group Pseudoponera), which coincidentally also form such groups according to Kempf [40], Schmidt [7], and MacKay and MacKay [4] (Table 2).

The study of the several clusters of Pachycondyla sensu Brown using the karyograph method (Figure 4) shows the clustering of species within the Pachycondyla sensu stricto group, all with a large number of acrocentric chromosomes, of species of Pseudoponera, with predominately metacentric chromosomes, and the great variation found in the karyotypes of species classified within the group Neoponera. The point distribution suggests that the most frequent rearrangements in these karyotypes were centric fissions and pericentric inversions (A-M type), and these rearrangements favor an increase in the number of chromosomes. Except for an isolated point on the right close to the $2 \mathrm{KM}$ limit in Figures 4 and 5 (which represents the population of Pachycondyla apicalis (Latreille, 1802) from Uruçuca), the karyotypes with larger numbers of chromosomes also tend to have mostly acrocentric chromosomes.

Some species have the same chromosome number but their morphology can be quite variable as a result of the aforementioned rearrangements. Six species have karyotypes that comprise only one morphological type of chromosome; in three of these species the karyotype is comprised of acrocentric chromosomes exclusively, and the other three species have karyotypes with only metacentric chromosomes (Table 2, Figures 4 and $5)$. In the karyograph, which shows taxa within the group Neoponera (11 species, 16 karyotypes, Figure 5),

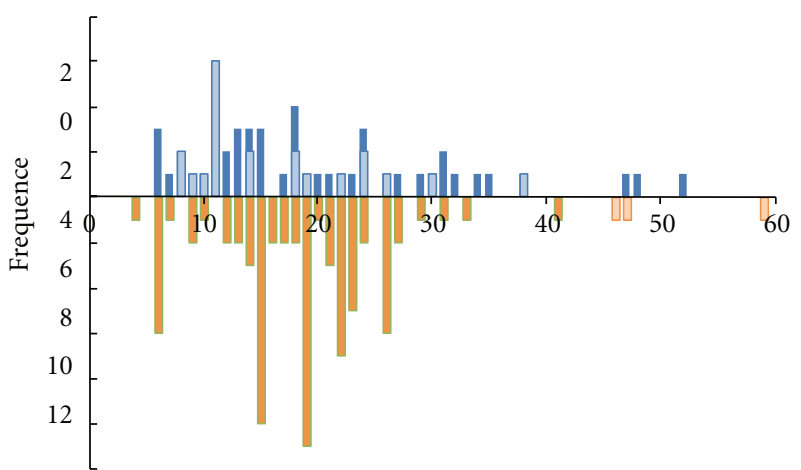

Haploid number of chromosomes $(n)$

$$
\begin{aligned}
& \text { - Neotropical Pachycondyla } \\
& \text { - Other Pachycondyla } \\
& \text { - Other Ponerinae }
\end{aligned}
$$

Figure 2: Distribution and frequency of haploid chromosome numbers in the Ponerinae subfamily, up to the $X$-axis: Pachycondyla spp.; down to the $X$-axis: other Ponerinae. The bars in lighter color in the range of "other Ponerinae" represent the known karyotypes in the Dinoponera genus (ref: as in Table 1 for Neotropical Pachycondyla spp.; for the others (genera Anochetus, Centromyrmex, Cryptopone, Diacamma, Dinoponera, Hypoponera, Leptogenys, Odontomachus, Odontoponera, Platythyrea, Ponera): [19, 36, 37, 39], Hypoponera spp.: $n=6$, 19; Leptogenys spp.: $n=15,21$; Platythyrea spp.: $n=20,22$; Thaumatomyrmex spp.: $n=10,21,31$ [Mariano et al., unpublished information]).

we highlighted the clusters of species within the apicalis, crenata, emiliae, foetida, and verenae groups.

Finally, we hypothesized the possible pathways of karyotype evolution in several groups of the Neotropical Pachycondyla sensu Brown for which we have enough data (nomenclature according to the last column of Table 1): Neoponera apicalis, Neoponera crenata, Neoponera foetida, Neoponera verenae, Pseudoponera and Pachycondyla sensu stricto. The representation (Figure 6) follows the model suggested by Imai and Crozier [27] developed for the interpretation of mammal karyotype evolution and is based on a hypothesis of karyotype variation essentially driven by fission.

\section{Discussion}

We can observe groups associated to the taxonomic position of species (Table 1) and some coincided with Schmidt's proposal [7], which splits Pachycondyla into 13 clades, with Mayaponera and Neoponera (both endemic), Pseudoponera, and Pachycondyla for the Neotropical Region.

Contrary to what has been reported for genera such as Atta, Acromyrmex, and Pheidole, in which the species already studied have a constant or not so variable karyotype [19], the karyotype groupings are extremely variable in species of Pachycondyla as well as in some distinct populations of the nominal species. Chromosome morphology is also variable, and it is noteworthy that, in most karyotypes with large chromosome numbers $(n>11$, according to 


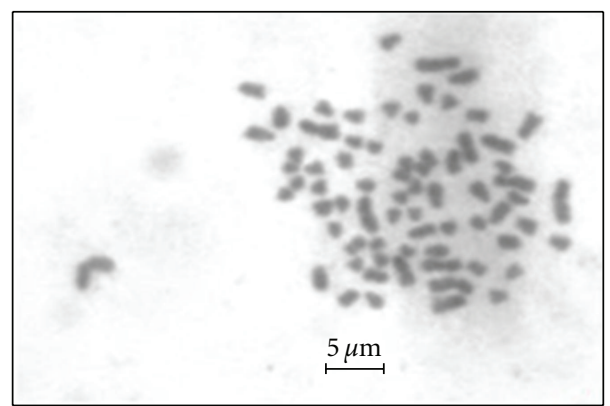

(a)

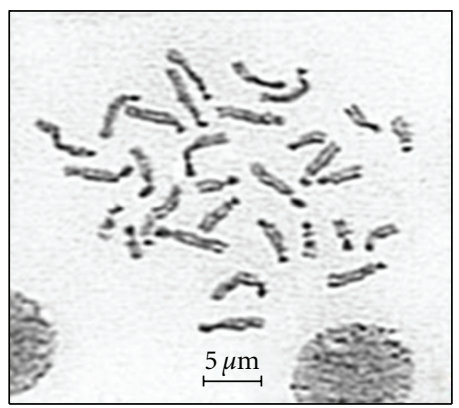

(c)

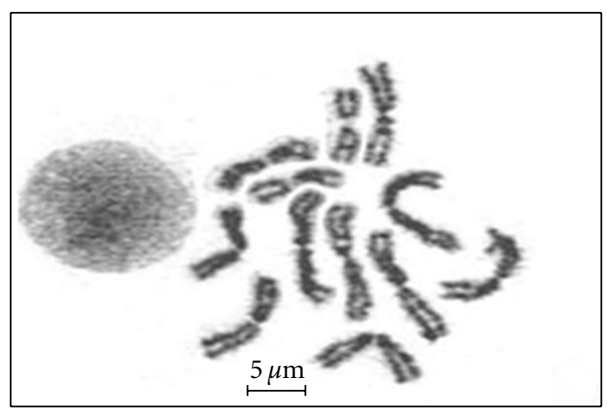

(b)

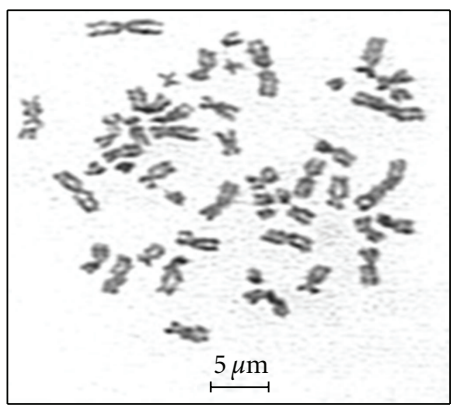

(d)

FIgURe 3: Metaphasic plates representing the different chromosome patterns found in Pachycondyla species. (a) Pachycondyla impressa, $2 n=70$, karyotype with a high number of chromosomes, mostly acrocentric. (b) Pachycondyla unidentata, $2 n=12$, karyotype with a low number of chromosomes, comprised exclusively by type M chromosomes of large size. (c) Pachycondyla arhuaca, $2 n=36$, Karyotype comprised exclusively by type A chromosomes. (d) Pachycondyla venusta, $2 n=54$, Karyotype comprised by types A and M chromosomes, a pattern found in many species and very common in the Neoponera group.

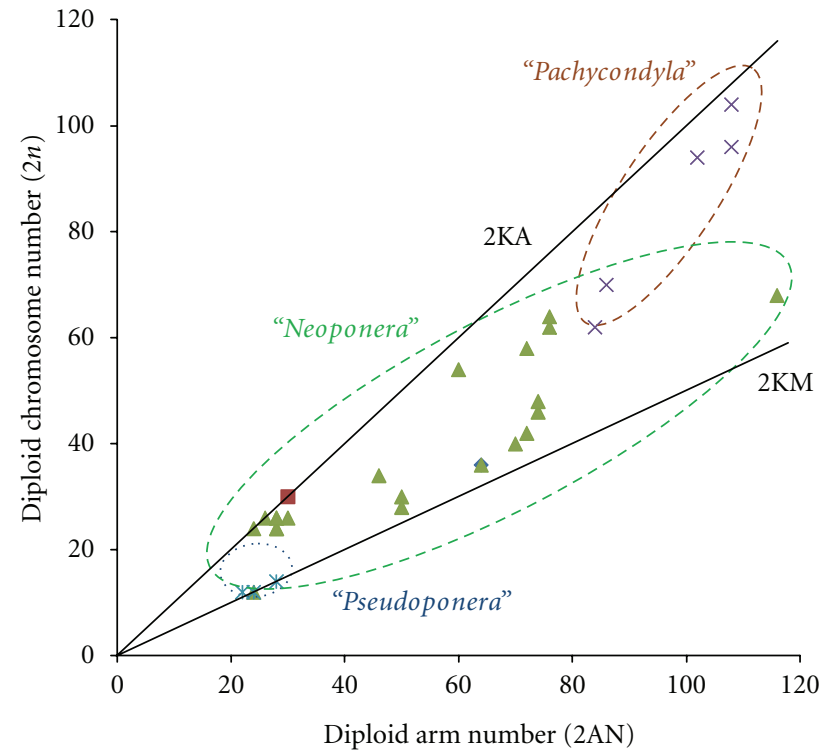

Figure 4: Karyograph of the Neotropical Pachycondyla sensu Brown. The ellipses circle the more representative species groups of our sampling according Schmidt [7] (see Table 1); two isolated points (square, diamond) represent single taxa not incorporated in a group (P. arhuaca, P. constricta).

the criteria of Imai et al., [41]), the chromosomes are submetacentric and acrocentric, which allows us to infer that fission and pericentric inversions (A-M ou M-A) are the most frequent chromosome rearrangements in the evolution

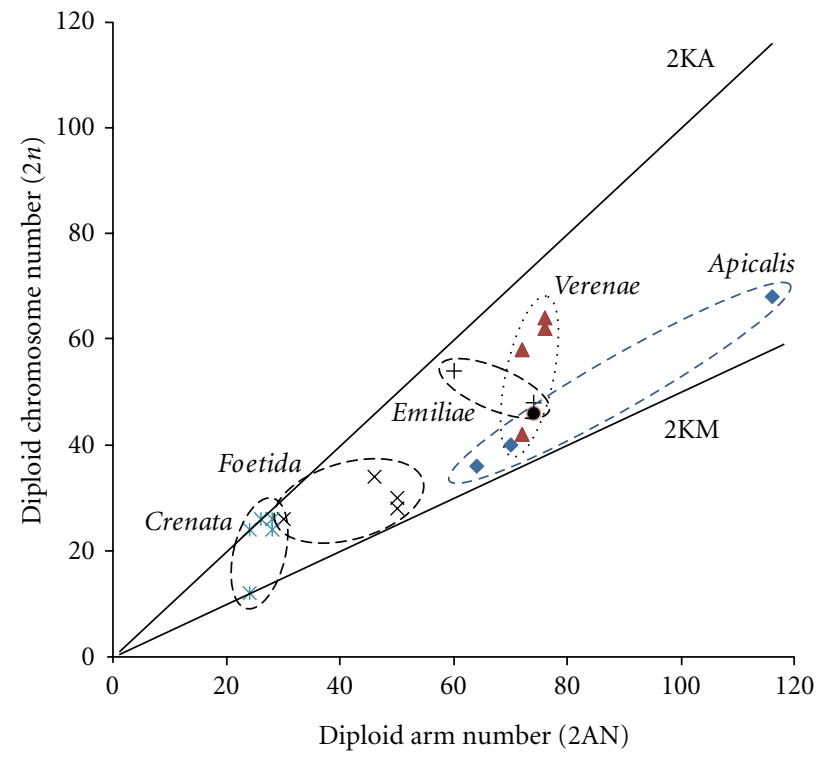

Figure 5: Karyograph of the Neotropical Neoponera according the Schmidt's proposal. The ellipses circle the more representative species groups (last column of Table 1); an isolated black circle represents a single species ( $P$. marginata) not incorporated in a group.

of these karyotypes. These rearrangements can be either responsible or coadjuvant in speciation processes, especially in the complexes of cryptic species sampled in this study (apicalis, verenae, and foetida groups). 


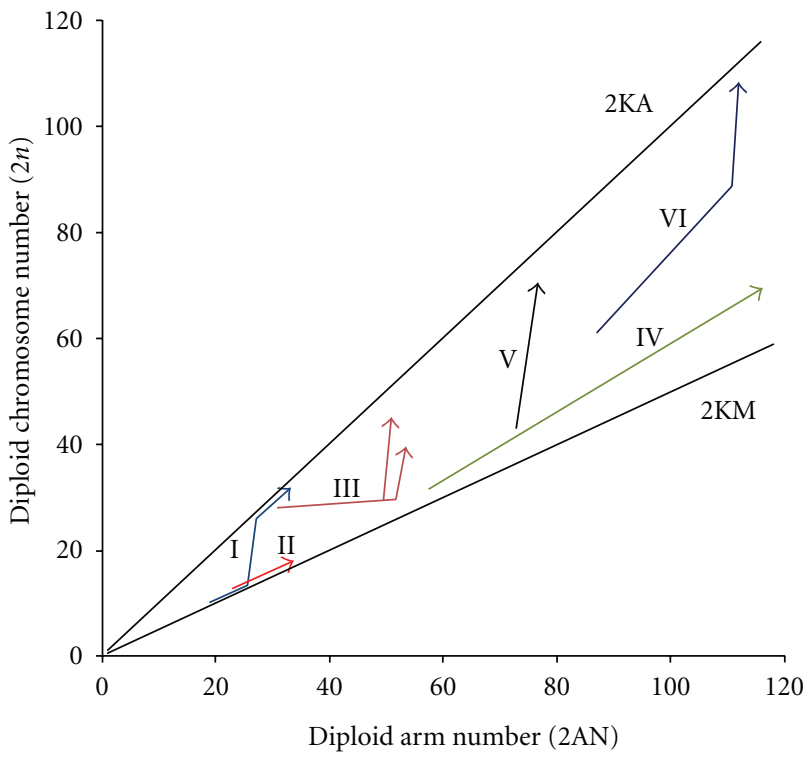

Figure 6: Possible pathways of karyotype evolution in several groups of Neotropical Pachycondyla sensu Brown. The Roman numbers correspond to the more representative species groups studied here (nomenclature according the last column of Table 1): I: Neoponera-crenata; II: Pseudoponera; III: Neoponera-foetida; IV: Neoponera-apicalis; V: Neoponera-verenae; VI: Pachycondyla sensu stricto. This schematic representation follows the suggested model of Imai and Crozier [27] for karyotypical evolution in mammals and is based on a hypothesis of a karyotype variation essentially driven by fission.

According to MacKay and MacKay [4], even though Pachycondyla sensu Brown is morphologically heterogeneous, the morphological characters were not consistent enough to justify splitting the group into distinct genera. However, similarly to Schmidt's [7], our results question the monophyly of Pachycondyla in its current acceptation. Thus, our results suggest the cooccurrence of multiple genera once there are totally independent patterns of karyotype evolution that strongly converge with Schmidt's conclusions [7]. We found groups with distinct patterns of karyotype evolution thus organized.

(a) Karyotypes with a large number of chromosomes and comprising mostly small acrocentric chromosomes in species within the Pachycondyla stricto sensu group (P. crassinoda, P. harpax, P. impressa, $P$, metanotalis, and $P$. striata) which most likely resulted from a succession of centric fission events (Figures 3(a), 6). These karyotypes follow the same pattern of those found in the three species of Dinoponera with available cytogenetic information [42], which is the sister genus of the clade Pachycondyla according to Schmidt [7].

(b) Karyotypes with a small chromosome number ( $n \leq$ 11 according to criteria in Imai et al. [41]) and comprising mostly metacentric chromosomes correspond to the pattern found in species within the group Pseudoponera (P. cauta, P. gilbertii, and P. stigma) and can be interpreted as little derived karyotype patterns which tend to undergo centric fission (Figure 3(b)).

(c) The karyotypes of Neoponera exemplify the karyotype evolution according to the model proposed by Imai et al. [21]: the karyotypes undergo successive cycles of rearrangements tending to increase the chromosome number by centric fission. The species included in Neoponera are considered the most diverse morphologically and behaviorally among the ponerine [7] and this diversity translates into the variety of karyotypes (Figure 3(c)).

(d) The case of populations within the taxa P. apicalis and $P$. verenae studied herein exemplifies an interesting evolutionary model based on biogeography. The two forms coexist along their range, which comprises practically only tropical and subtropical terrestrial environments in the Neotropical Region [25, 43]. A more refined analysis of the morphological criteria suggests that each nominal taxon is a complex of cryptic species of allopatric distribution [25], which is corroborated by the cytogenetic study: the apicalis and verenae complexes form two probable sister groups that probably evolved independently due mainly to centric fissions (verenae) and pericentric inversions (apicalis) (Figures 5 and 6).

All these examples adequately illustrate the karyotype heterogeneity in Pachycondyla and reinforce the argument of the cooccurrence of several genera, at least in the Neotropical region. The cytogenetic studies indicate groupings that do not seem to have recent ancestry and also strongly suggest the paraphyly of the "Pachycondyla problem," according to Ward [8], as each group follows a distinct evolutionary pattern (Figure 4).

Some of these patterns are not exclusive of the species represented herein; they have been reported in known ant karyotypes such as in species of the Australian genus Myrmecia [21] and corroborate the occurrence of different evolutionary patterns in insects.

The diversity of karyotypes found in the known species of Pachycondyla in the Neotropics is supported by the antiquity of this group of ants and reinforces a tendency observed in karyotypes of Formicidae: the increase and diversification of chromosome number and morphology in a basal subfamily such as Ponerinae contrasting with the low variation and relative stability in some genera of more derived subfamilies such as Dolichoderinae, Formicinae, and Myrmicinae [22, 44]. A similar phenomenon was observed in the Australian Myrmeciinae [21, 26], but the idea formerly well accepted that these ants are basal and ancestral is no longer supported by recent molecular phylogenies [45]. This situation leads to the very intriguing question of what is shared by the Myrmeciinae and Ponerinae to be so variable with respect to their karyotypes whereas karyotypes seem to be rather uniform in related subfamilies?

Among the ants, it is noteworthy the occurrence of cryptic species complexes and sibling species: morphologically indistinguishable species recently diverged (siblingspecies) or that maintain strongly convergent characters 
(cryptic species), and not separable using the traditional methods of identification $[10,11]$, in which characters such as behavior, chemical signature, and karyotype composition act as mechanisms of reproductive isolation (in Neotropical Pachycondyla, see, for instance, Lucas et al. [46]). Such a phenomenon has been reported for ants and many other organisms, and there are likely to be different speciation processes as there are multiple species concepts [47]. Thus, the use of different criteria for the description of species (alpha level taxonomy) is justified, and these criteria have been tested using the integrated taxonomy approach, which consists of using complementary areas such as molecular genetics, ecology, behavior, cytogenetics, and chemistry among others [48]. This approach strengthens the necessity of interdisciplinary studies and emphasizes the importance of multiple tools for taxonomic studies, a consensus among several authors [48, 49]. Therefore, besides confirming the validity of a species recognized by other methods, cytogenetics can contribute to the study of the origin and definition of species limits, as well as to the understanding of the evolution of organisms [49]. We hope our study will shed some light on the classification of the genus Pachycondyla, which still needs further disentangling.

\section{Acknowledgments}

The authors acknowledge D Denis, JRM Santos, JCS Carmo and Sr. Manoel for their help in field work and LSR Nascimento and EA Santos for their help in slide preparation. This study was funded by FAPESB and CNPq. JHCD acknowledges his research grant from CNPq. This is a contribution of the Program PRONEX FAPESB CNPq, project PNX0011/2009: "Rede Multidisciplinar de Estudos sobre Formigas Poneromorfas do Brasil." In accordance with section 8.6 of the ICZNs International Code of Zoological Nomenclature, printed copies of the edition of Psyche containing this article are deposited at the following six publicly accessible libraries: Green Library (Stanford University), Bayerische Staatsbibliothek, Library_ECORC (Agriculture \& Agri-Food Canada), Library-Bibliotheek (Royal Belgium Institute of Natural Sciences), Koebenhavns Universitetsbibliotek, University of Hawaii Library.

\section{References}

[1] J. Rust and N. M. Andersen, "Giant ants from the Paleogene of Denmark with a discussion of the fossil history and early evolution of ants (Hymenoptera: Formicidae)," Zoological Journal of the Linnean Society, vol. 125, no. 3, pp. 331-348, 1999.

[2] B. Bolton, A New General Catalogue of the Ants of the World, Harvard University Press, Cambridge, Mass, USA, 1995.

[3] B. Bolton, G. Alpert, P. S. Ward, and P. Naskrecki, Bolton's Catalogue of Ants of the World 1758-2005, Harvard University Press, Cambridge, Mass, USA, Harvard University Press.

[4] W. P. MacKay and E. E. MacKay, The Systematics and Biology of the New World Ants of the Genus Pachycondyla (Hymenoptera: Formicidae), The Edwin Mellen Press, Lewiston, NY, USA, 2010.
[5] W. W. Kempf, "Catálogo abreviado das formigas da Região Neotropical," Studia Entomoogica, vol. 15, pp. 3-344, 1972.

[6] W. L. Brown Jr., "A comparison of the Hylean and Congo-West African rain forest ant faunas," in Tropical Forest Ecosystems in Africa and South America: A Comparative Review, B. J. Meggers, E. S. Ayensu, and W. D. Duckworth, Eds., pp. 161185, Smithsonian Institution Press, Washington, DC, USA, 1973.

[7] C. A. Schmidt, Molecular philogenetics and taxonomic revision of ponerine ants (Hymenoptera: Formicidae: Ponerinae), Ph.D. thesis, University of Arizona, 2010.

[8] P. S. Ward, "Integrating molecular phylogenetic results into ant taxonomy (Hymenoptera: Formicidae)," Myrmecological News, vol. 15, pp. 21-29, 2011.

[9] M. S. Guerra and M. J. Souza, Como Observar Cromossomos: Um Guia de Técnicas em Citogenética Vegetal, Animal e Humana, Ribeirão Preto, São Paulo, Brazil, 2002.

[10] D. Bickford, D. J. Lohman, N. S. Sodhi et al., "Cryptic species as a window on diversity and conservation," Trends in Ecology and Evolution, vol. 22, no. 3, pp. 148-155, 2006.

[11] B. Seifert, "Cryptic species in ants (Hymenoptera: Formicidae) revisited: we need a change in the alpha-taxonomic approach," Myrmecological News, vol. 12, pp. 149-166, 2009.

[12] F. Baldanza, L. Gaudio, and G. Viggiani, "Cytotaxonomic studies of Encarsia Forster (Hymenoptera: Aphelinidae)," Bulletin of Entomological Research, vol. 89, no. 3, pp. 209-215, 1999.

[13] H. Hoshiba and H. T. Imai, "Chromosome evolution of bees and wasps (Hymenoptera, Apocrita) on the basis of Cbanding pattern analyses," Japanese Journal of Entomology, vol. 61, no. 3, pp. 465-492, 1993.

[14] V. E. Gokhman, "Implication of chromosomal analysis for the taxonomy of parasitic wasps (Hymenoptera)," Entomological Review, vol. 86,, pp. 1-10, 2006.

[15] V. E. Gokhman and V. G. Kuznetsova, "Comparative insect karyology: current state and applications," Entomological Review, vol. 86, pp. 352-368, 2006.

[16] M. Ridley, Evolução, Artmed, Porto Alegre, Brasil, 2003.

[17] H. C. MacGregor, An Introduction to Animal Cytogenetics, Chapman \& Hall, London, UK, 1993.

[18] C. S. F. Mariano, J. H. C. Delabie, L. A. O. Campos, and S. G. Pompolo, "Trends in karyotype evolution in the ant genus Camponotus (Hymenoptera: Formicidae)," Sociobiology, vol. 42, no. 3, pp. 831-839, 2003.

[19] P. Lorite and T. Palomeque, "Karyotype evolution in ants (Hymenoptera: Formicidae), with a review of the known ant chromosome numbers," Myrmecological News, vol. 13, pp. 89$102,2010$.

[20] D. Agosti and N. F. Johnson, “Antbase," version (05/2005), 2009, antbase.org .

[21] H. T. Imai, R. W. Taylor, and R. H. Crozier, "Experimental bases for the minimum interaction theory. I. Chromosome evolution in ants of the Myrmecia pilosula species complex (Hymenoptera: Formicidae: Myrmeciinae)," Japanese Journal of Genetics, vol. 69, no. 2, pp. 137-182, 1994.

[22] C. S. F. Mariano, Evolução cariotípica em diferentes grupos de Formicidae, Ph.D. thesis, Universidade Federal de Viçosa, Minas Gerais, Brasil, 2004.

[23] C. S. F. Mariano, S. G. Pompolo, S. Lacau, and J. H. C. Delabie, "Questions sur la monophylie du taxon Pachycondyla Smith, 
1858: approche cytogénétique sur le sous-genre Pachycondyla sensu Emery, 1901 (Hymenoptera: Formicidae: Ponerinae)," Bulletin de la Société Entomologique de France, vol. 111, pp. 299-304, 2006.

[24] C. S. F. Mariano, S. G. Pompolo, D. S. Borges, and J. H. C. Delabie, "Are the Neotropical ants Pachycondyla crenata (Roger) and Pachycondyla mesonotalis (Santschi) (Formicidae, Ponerinae) good species? A cytogenetic approach," Myrmecologische Nachrichten, vol. 8, pp. 277-280, 2006.

[25] J. H. C. Delabie, C. S. F. Mariano, L. F. Mendes, S. G. Pompolo, and D. Fresneau, "Problemas apontados por estudos morfológicos, ecológicos e citogenéticos no gênero Pachycondyla na Região Neotropical: o caso do complexo apicalis," in Insetos Sociais: da Biologia à Aplicação, E. F. Vilela, I. A. Santos, J. H. Schoereder et al., Eds., pp. 196-222, Editora da Universidade Federal de Viçosa, Minas Gerais, Brazil, 2008.

[26] H. T. Imai, R. H. Crozier, and R. W. Taylor, "Karyotype evolution in Australian ants," Chromosoma, vol. 59, no. 4, pp. 341-393, 1977.

[27] H. T. Imai and R. H. Crozier, "Quantitative analysis of directionality in mammalian karyotype evolution," The American Naturalist, vol. 116, no. 4, pp. 537-569, 1980.

[28] H. T. Imai, T. Maruyama, T. Gojobori, Y. Inoue, and R. H. Crozier, "Theoretical bases for karyotype evolution. 1. The minimum-interaction hypothesis," The American Naturalist, vol. 128, pp. 900-920, 1986.

[29] H. T. Imai, R. W. Taylor, M. W. Crosland, and R. H. Crozier, "Modes of spontaneous chromosomal mutation and karyotype evolution in ants with reference to the minimum interaction hypothesis," Japanese Journal of Genetics, vol. 63, no. 2, pp. 159-185, 1988.

[30] H. T. Imai, Y. Satta, and N. Takahata, "Integrative study on chromosome evolution of mammals, ants and wasps based on the minimum interaction theory," Journal of Theoretical Biology, vol. 210, no. 4, pp. 475-497, 2001.

[31] H. T. Imai, Y. Satta, M. Wada, and N. Takahata, "Estimation of the highest chromosome number of eukaryotes based on the minimum interaction theory," Journal of Theoretical Biology, vol. 217, no. 1, pp. 61-74, 2002.

[32] A. E. Spotorno, L. I. Walker, S. V. Flores, M. Yevenes, J. C. Marín, and C. Zuleta, "Evolución de los filotinos (Rodentia, Muridae) en los Andes del Sur," Revista Chilena de Historia Natural, vol. 74, pp. 151-166, 2001.

[33] A. T. Sumner, Chromosomes: Organization and Function, Blackwell Publishing, Oxford, Uk, 2003.

[34] M. S. Guerra, FISH: Conceitos e Aplicações na Citogenética, Sociedade Brasileira de Genética, Ribeirão Preto, Brasil, 2004.

[35] C. S. F. Mariano, J. H. C. Delabie, J. R. M. Santos, and S. G. Pompolo, "Evolução cariotipica em Pachycondyla spp. (Ponerinae) neotropicais," Biológico, vol. 69, suplemento 2, pp. 409-412, 2007.

[36] C. S. F. Mariano, S. G. Pompolo, L. A. C. Barros, E. MarianoNeto, S. Campiolo, and J. H. C. Delabie, "A biogeographical study of the threatened ant Dinoponera lucida Emery (Hymenoptera: Formicidae: Ponerinae) using a cytogenetic approach," Insect Conservation and Diversity, vol. 1, pp. 161$168,2008$.

[37] C. S. F. Mariano, I. S. Santos, S. Groc et al., "The karyotypes of Gigantiops destructor (Fabricius) and other ants from French Guiana (Formicidae)," Annales de la Société Entomologique de France, vol. 47, pp. 140-146, 2011.

[38] H. T. Imai, "Mutability of constitutive heterochromatin (Cbands) during eukaryotic chromosomal evolaution and their cytological meaning," Japanese Journal of Genetics, vol. 66, no. 5, pp. 635-661, 1991.

[39] I. S. Santos, M. A. Costa, C. S. F. Mariano, J. H. C. Delabie, V. Andrade-Souza, and J. G. Silva, "A cytogenetic approach to the study of Neotropical Odontomachus and Anochetus ants (Hymenoptera: Formicidae)," Annals of the Entomological Society of America, vol. 103, no. 3, pp. 424-429, 2010.

[40] W. W. Kempf, "As formigas do gênero Pachycondyla Fr. Smith no Brasil," Revista Brasileira de Entomologia, vol. 10, pp. 189204, 1962.

[41] H. T. Imai, C. Baroni Urbani, M. Kubota et al., "Karyological survey of Indian ants," Japanese Journal of Genetics, vol. 59, pp. $1-32,1984$.

[42] C. S. F. Mariano, E. C. Sposito, A. L. Lopes, S. G. Pompolo, and J. H. C. Delabie, "Análises cariotípicas comparativas no gênero Dinoponera Roger (Ponerinae: ponerini)," in Proceedings of the 17th Simpósio de Mirmecologia, pp. 140-142, Campo Grande, MG, Brazil, 2005.

[43] A. L. Wild, "Taxonomic revision of the Pachycondyla apicalis species complex (Hymenoptera: Formicidae)," Zootaxa, no. 834, pp. 1-25, 2005.

[44] C. S. F. Mariano, "Questões atuais da biologia das formigas vistas sob um ângulo citogenético," in Proceedings of the 20th Simpósio de Mirmecologia, Ouro Preto, MG, Brazil, 2009.

[45] C. S. Moreau, C. D. Bell, R. Vila, S. B. Archibald, and N. E. Pierce, "Phylogeny of the ants: diversification in the age of angiosperms," Science, vol. 312, no. 5770, pp. 101-104, 2006.

[46] C. Lucas, D. Fresneau, K. Kolmer, J. Heinze, J. H. C. Delabie, and D. B. Pho, "A multidisciplinary approach to discriminating different taxa in the species complex Pachycondyla villosa (Formicidae)," Biological Journal of the Linnean Society, vol. 75, no. 2, pp. 249-259, 2002.

[47] E. Mayr, "Wu's genic view of speciation," Journal of Evolutionary Biology, vol. 14, no. 6, pp. 866-867, 2001.

[48] B. C. Schlick-Steiner, F. M. Steiner, B. Seifert, C. Stauffer, E. Christian, and R. H. Crozier, "Integrative taxonomy: a multisource approach to exploring biodiversity," Annual Review of Entomology, vol. 55, pp. 421-438, 2010.

[49] J. M. Padial and I. De La Riva, "A response to recent proposals for integrative taxonomy," Biological Journal of the Linnean Society, vol. 101, no. 3, pp. 747-756, 2010. 

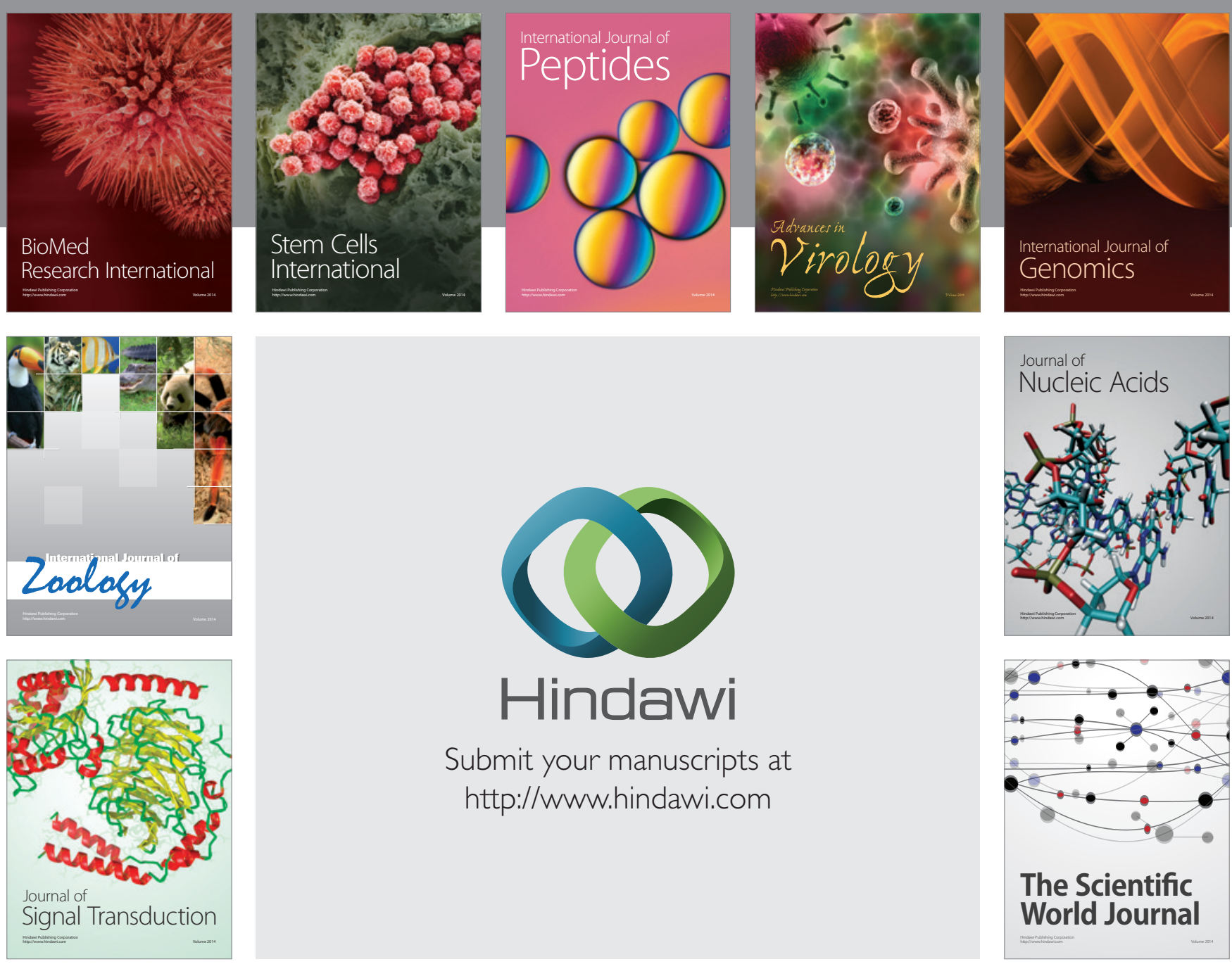

Submit your manuscripts at

http://www.hindawi.com
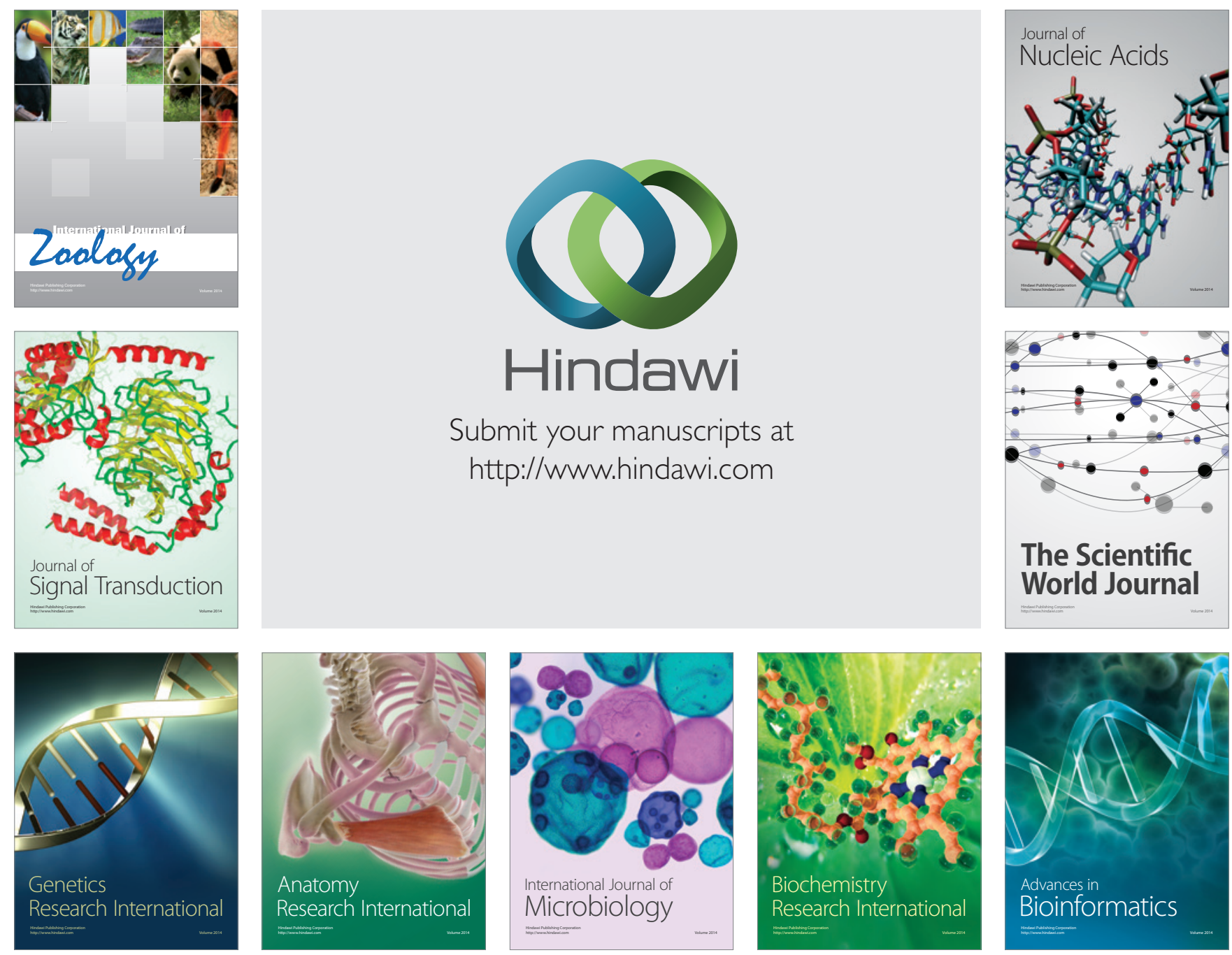

The Scientific World Journal
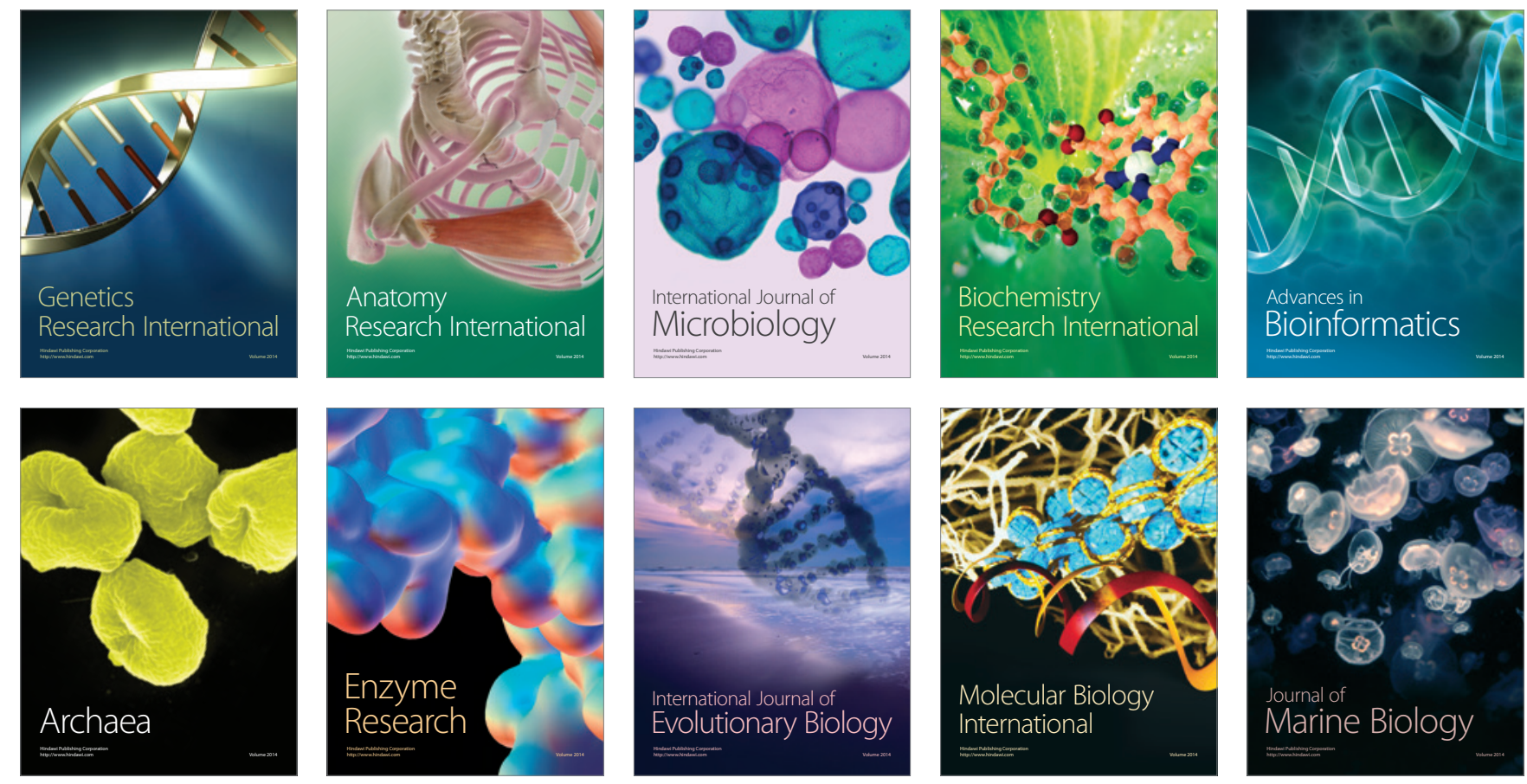